\title{
HIGHER EDUCATION AND TRAINING TOWARDS GLOBAL COMPETITIVENESS AND HUMAN DEVELOPMENT IN INDONESIA
}

\author{
Ifan DEFFINIKA* \\ Universitas Negeri Malang, Faculty of Social Sciences, Department of Geography, Indonesia, e-mail: ifan.deffinika.fis@um.ac.id \\ Inanditya Widiana PUTRI \\ Universitas Negeri Malang, Faculty of Social Sciences, Department of Geography, Indonesia, e-mail: inandityaputri@gmail.com \\ Khairunnisa Boru ANGIN \\ Universitas Negeri Malang, Faculty of Social Sciences, Department of Geography, Indonesia, e-mail: khairunnisaba@gmail.com
}

\begin{abstract}
Citation: Deffinika, I., Putri, I.W., \& Angin, K.B. (2021). HIGHER EDUCATION AND TRAINING TOWARDS GLOBAL COMPETITIVENESS AND HUMAN DEVELOPMENT IN INDONESIA. GeoJournal of Tourism and Geosites, 38(4), 12801288. https://doi.org/10.30892/gtg.38436-770
\end{abstract}

\begin{abstract}
This research explains about Indonesian labor competitiveness from perspective of the 5th pillar GCI (education and training). The purpose is to (1) measure the readiness of Indonesian labor at the ASEAN level and (2) ana-lyzed relationship between GCI and HDI. This research was using descriptive and inferential analysis. The re-sults show Indonesia is in fourth place in ASEAN. Coefficient correlation between the 5th pillar of CGI and HDI is 0.874 . This explain the quality of human development is strongly related to global competitiveness. It can be interpreted that increasing human resources will also have positive impact on global competitiveness trough improving education.
\end{abstract}

Key words: competitiveness, human resources, aec, industrial revolution 4.0, education and training

$* * * * * *$

\section{INTRODUCTION}

Sustainable Development Goals (SDGs) target concerning various issues about development, from poverty to international cooperation. Every country that is a member of the United Nations (UN) has agreed on and implemented this global SDGs commitment, as well as Indonesia. As a member of the United Nations, Indonesia has committed to implementing SDGs to improve the welfare and social quality of its people (Afandi, 2017). Global partnerships and cooperation are SDGs goals that can be realized by a strong commitment between countries. Partnerships and cooperation between countries in ASEAN are getting better with the formation of the ASEAN Economic Community (AEC). AEC is the realization of the Southeast Asian free market with the aim of increasing competitiveness and attracting foreign investment (Warta Ekspor, 2015). Foreign investment is one of the components that make up the Gross Domestic Product (GDP). The existence of foreign investment can be used by each country to improve the public services they have. This is done to achieve the existence of a country's national development (Pramono and Rofi, 2013). The existence of foreign investment will also have an impact on increasing employment which leads to community welfare (Puri, 2014).

As a member of the ASEAN Economic Community, Indonesia has many superior sectors that have great potential in the AEC competition (Nursyamysi and Subarkah, 2016). However, Indonesia is not ready to rely solely on the available sectors if there is no balance between managing Natural Resources and Human Resources (HR). Human resource development is an important part of increasing the competitiveness of labor. Education and training are part of the workforce development requirement. With the fulfillment of education and training, a person will be able to get work autonomy and will lead to an increase in the career ladder. This is a challenge for developing countries ( Khan et al., 2020; de Saxe Zerden et al., 2019). Many countries such as China and South Korea see the importance of developing human resources in economic development (Adam, 2017). In line with its vision that reflects on the successful experience of the European Union, ASEAN hopes that by 2020 the Southeast Asian region will become a single market base. It is hoped that in this ASEAN Economic Community (AEC) the market can product goods, services, investment, capital, and skilled labor can move freely (Deffinika, 2014).

Asia, as the largest continent with a high population density, must always pay attention to the state of human development in each of its regions, because this greatly affects national development. The education dimension in the Human Development Index is represented by years of school taken by the community in an area. The awareness of the population in an area of the importance of education can change the country to be better. This change is an indication of the developed or undeveloped human resources in a country (Pramono and Rofi, 2013). The progress of a country does not only come from the availability of its natural resources, but is largely determined by the quality of human resources in managing these natural resources. Human resource development is the key point in optimizing national development. Improving the quality of human resources can be done through education. Human resource development needs to be

\footnotetext{
* Corresponding author
} 
managed effectively and efficiently, both in terms of quantity and quality (Suratini, 2017). Optimal human resource development can encourage a country to compete globally (Afandi, 2017).

Indonesia is predicted to have a demographic bonus, which means that the number of people in the productive age population will exceed the unproductive population (Umar, 2018). Based on (BPS RI (2018), in 2017 the number of productive age population in Indonesia now is $181,354,900$ people, while the number of non-productive people is $86,719,500$ people. Population growth and the existence of a demographic bonus that will be achieved by Indonesia in 2030-2035 are expected to provide benefits in achieving national development. The demographic bonus will clearly present opportunities and challenges for Indonesia. Various preparations must be made properly to achieve the demographic bonus so that it does not become a disaster for the country. Productive age population in Indonesia needs to be prepared to be competitive in the global market, especially in the era of the industrial revolution 4.0. It is hoped that the population of productive age can increase and promote national development. Not only that, but government support is also needed to support the success of national development (Ayu, 2018).

Employment wage done repeatedly would create a labor market and increase economic growth (Garidzirai and Pasara, 2020). In the era of the industrial revolution 4.0, many opportunities opened up for labor in Indonesia, especially in the manufacturing sector. In this sector, it is expected that each labor will have expertise in line with ongoing technological developments. To create a better quality of human resources, it is necessary to implement a program of upgrading and renewing skills for the labor based on current needs (Indonesian Ministry of Industry, 2018). Airlangga Hartarto from Indonesian Ministry of Industry (2018), in a press release said that one of the priority programs in the roadmap making for Indonesia 4.0 was improving the quality of Indonesian human resources. Based on this, Indonesia plans to change the education curriculum by emphasizing the fields of Science, Technology, Arts, and Mathematics (STEAM). Zahidi, the head of the WEF's new economy and society, said that a country can develop and prosper if it succeeds in pursuing innovation. Not only investing in technology, but every country must invest in the human resources and institutions they have. With the advancement of these resources and institutions, technological advances will also be realized (Ventura, 2018).

Human resource development can be started by developing basic skills as a human capital. This human capital will not only provide skills to get a job but also make a person able to function optimally in their community (Chowa, 2019). The first basic skill that must be developed is life skill, where a person must be able to understand oneself and be responsible for their social environment. The second skill is learning and innovation skill where a person is required to always think critically so that they can solve complex problems and be able to collaborate and always provide new innovations. The third skill is literacy skill. With a variety of knowledge possessed as well as mastery of technology, it is hoped that someone can solve various daily problems that exist (Zubaidah, 2019). Preparation to compete in the global market has an important role that cannot be ignored. In the era of the Industrial Revolution 4.0, people needed to have basic abilities, not only knowledge-based abilities, but also knowledge that was applied in real terms (Budiati et al., 2018). Haryono (2018) said, now that Indonesia has entered the era of free trade, Indonesians must be able to compete globally. The World Economic Forum (WEF) regularly publishes a Global Competitiveness Report to evaluate competitiveness in various countries. Global Competitiveness Index $(\mathrm{GCI})$ is a starting point tool for the government and the private sector. The global competitiveness index provides information on what is needed to increase growth and reduce poverty.

The report of the World Economic Forum in 2016 shows that the ranking of world competitiveness in the top 10 is dominated by countries in Europe. Switzerland is the country that has the highest competitive score for two consecutive years, with a score of 5.81. In 2016, Indonesia was ranked $41^{\text {st }}$ its means that Indonesia experienced a decrease in the competitive level of 4 levels from the previous year. Indonesia itself has a score that is still far below Singapore, Malaysia and Thailand (Raimanu, 2016). According to the Coordinating Board for the Head of Investment, Indonesia's downgrade of world competitiveness was due to the government's lack of economic policies.

The government is considered unaware when commodity prices are high. As a result, the government needs to increase competitiveness through the development of human resources in terms of education and skills to face the challenges and opportunities in the 4.0 industrial revolution. Achieving development in the era of the industrial revolution 4.0 requires a population with competitive international human resource quality. Based on the explanation above, this research will identify the competitiveness of Indonesian labor in the education and training sector. It will also be seen whether there is a relationship between the Global Competitiveness Index and the Human Development Index. The main objective of this research is to measure the readiness of the competitiveness of Indonesian labor in facing various global challenges from the Revolutionary Industry 4.0 from the education and training sector.

\section{METHODS}

This research uses a quantitative approach with an inferential analysis to measure Indonesian labor readiness using education and trainee indicator, which are one of the indicators of the global competitiveness index. Global Competitiveness Index (GCI) is composed of three Sub-indexes, (1)basic requirements Sub-index, (2)efficiency enhancer Sub Index, and (3)innovation and sophistication factor Sub-index. All indicators come from a combination of data by World Economic Forum's Executive Opinion Survey then compiled into 12 pillars of the Global Competitiveness Index (GCI) of the Industrial Revolution 4.0. (Schwab, 2018). The constituent components and weight can be seen in the Figurel. The weight of the competitiveness index measurement depends on the country classification. WEC classifies countries based on the stages of development based on per capita income. Indonesia's per capita income in USD is 3,893, so that it can be categorized into Stage 2. In countries classified as stage 2, the greatest weight lies in the Efficiency Enhancer Sub Index. One of the indicators on the efficiency enhancer Sub Index is higher education and training. Figure 1 show further information about GCI composit index. 
Therefore the focus of this research will be to identify the competitiveness of the labor from the indicators of higher education and training. This indicator is an important issue on labor productivity which will indirectly impact the country's

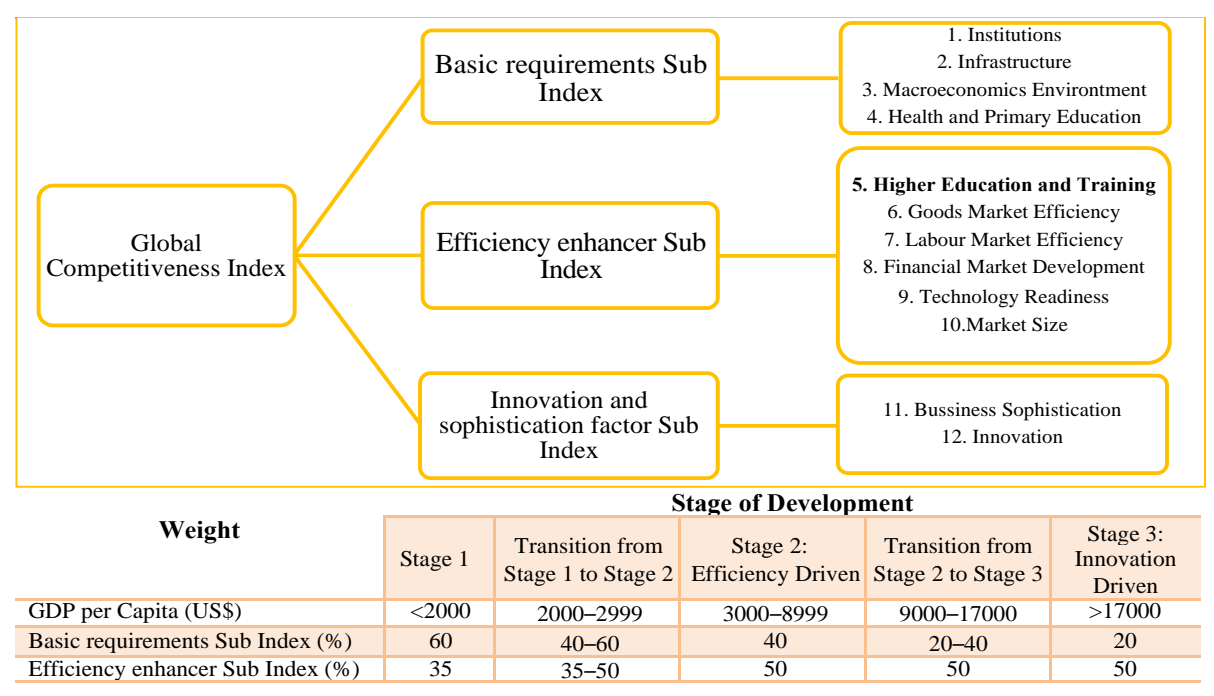

Figure 1. GCI Component and Weights of Sub-Index Values Based on Development Stage (Source: Global Competitiveness Report Schwab, 2018) economy. In the era of globalization, a country needs educated and skilled labor who are able to perform complex tasks and can adapt quickly to analyze changes occurring in their environment. This research uses Labour Force Concept (Adam, 2017) with subjects Indonesian labor status aged 15 years and over. The labor readiness is intended to measure the quality or ability of Indonesian labor by using the Global Competitiveness Index. The framework in this research can be seen in Figure 2.

Table 1 . Reliability test results

\begin{tabular}{|c|c|}
\hline \multicolumn{2}{|c|}{ Reliability Statistics } \\
\hline Cronbach's Alpha & N of Items \\
\hline $\mathbf{7 7 4}$ & 3 \\
\hline
\end{tabular}

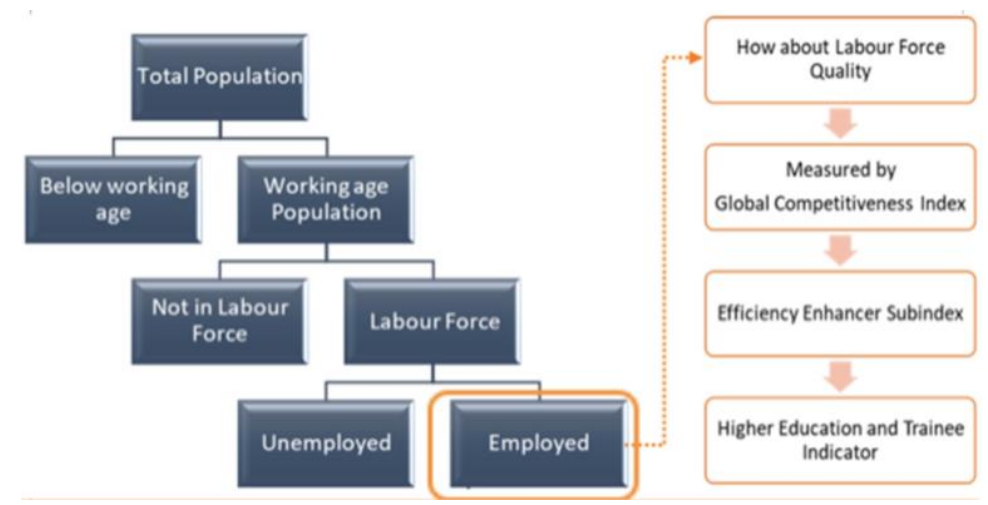

Figure 2. Research Framework

Table 2. Validity Test Results

\begin{tabular}{|c|c|c|}
\hline \multicolumn{3}{|c|}{ Validity test } \\
\hline & $\begin{array}{c}\text { The } 5^{\text {th }} \text { Global } \\
\text { Competitiveness } \\
\text { Index }\end{array}$ & $\begin{array}{c}\text { Global } \\
\text { Competitivenes } \\
\text { s Index }\end{array}$ \\
\hline $\begin{array}{c}\text { Correlation } \\
\text { Coefficient }\end{array}$ & $\mathbf{0 . 8 7 4} * *$ & $\mathbf{0 . 8 5 0} * *$ \\
\hline $\begin{array}{c}\text { Sig. } \\
\text { (2-tailed) }\end{array}$ & 0.005 & 0.007 \\
\hline $\mathrm{N}$ & 8 & 8 \\
\hline
\end{tabular}

This research focuses on the measurement of indicators of higher education quality and training. Higher education quality and training are crucial issues for economies that want to move up the value chain beyond simple production processes and products. Nowadays the globalizing economy requires countries to preserve well-educated labor who are able to perform complex tasks and adapt quickly to analyze changes in their environment and the evolving needs of production systems. The pillar measures secondary and tertiary enrolment rates as well as the quality of education as evaluated by business leaders. The extent of staff training is also taken into consideration because of the importance of vocational and continuous on work training which is desolate in many economies for ensuring a constant escalation of labor' skills. The moment the country becomes more competitive, it will escalate productivity and salary will rise with advancing development. The countries will move into the efficiency that drives the development stage, when they must begin to develop more efficient production processes and escalate product quality because the salary has risen and they cannot escalate prices. This point towards competitiveness is escalating driven by higher education and training ( $5^{\text {th }}$ pillar), efficient goods markets $\left(6^{\text {th }}\right.$ pillar), well-functioning labor markets $\left(7^{\text {th }}\right.$ pillar), developed financial markets $\left(8^{\text {th }}\right.$ pillar $)$, the ability to harness the benefits of existing technologies $\left(9^{\text {th }}\right.$ pillar), and a large domestic or foreign market $\left(10^{\text {th }}\right.$ pillar).

Finally, as countries move into the innovation-driven stage. The data source in this research uses secondary data obtained through the global competitiveness index issued by the World Economic Forum (WEF) and labor data issued by Badan Pusat Statistik (BPS). The existing data will be processed into a single tabulation, then used to explain the condition of the $5^{\text {th }}$ pillar of the Global Competitiveness Index (GCI) in Indonesia. Data analyzed by using descriptive analysis to compare Indonesia data with other ASEAN countries. This is done to see to what extent Indonesia can compete with other countries in terms of labor education and training. Spearman non-parametric correlation analysis also used to measuse relationship between the Indonesia's human resources development index (HDI) and the condition of the competitiveness of Indonesian labor in the fields of education and training. This can be seen based on the HDI score and the GCI score. There are three variables used in this research, namely the HDI score of ASEAN countries (as the independent variable / Y), the Global Competitiveness Index score of the 5 pillars of ASEAN countries (as the dependent variable / $\mathrm{X}_{1}$ ), and the overall score of the ASEAN countries Global Competitiveness Index (as the dependent variable / $\mathrm{X}_{2}$ ).

Before carrying out all the tests that have been determined, the previous researcher conducted a reliability and validity test to ascertain whether this research could be carried out. The reliability test was conducted to see whether the research 
instruments owned by the researcher could be used in this research. The validity test is carried out to see whether this research instrument can perform its function properly. From the validity test, researchers can also find out whether the instrument used can achieve the intended target or not. The results of the reliability test showed in Table 1. Cronbach's Alpha value on the variable that the researcher used was 0.774 . This value indicates that research instrument is reliable and can be used. This is indicated by Cronbach's Alpha value $>0.6$. The results of the validity test showed in Table 2 . The correlation coefficient between the three variables, namely the $5^{\text {th }}$ pillar of the Global Competitiveness Index score, the Total Global Competitiveness Index, and the Human Development Index, which show that the number is higher that the $\mathrm{r}$ table value that has been set, that is 0.707 . The correlation coefficient result between the Human Development Index variable and the total $5^{\text {th }}$ pillar of the Global Competitiveness Index is 0.874 . Not much different from the correlation of HDI and the $5^{\text {th }}$ pillar of GCI results, the validity test between the Human Development Index variable and the total score of the Global Competitiveness Index is 0.85 . Reliability and validity test results show that the research instrument can be used and can perform its functions properly, by achieving the goals that have been aimed.

\section{RESULTS AND DISCUSSIONS}

\section{Labor Characteristics}

By joining the AEC, Indonesia has challenged themself, especially in terms of optimizing natural and human resources. Good resource management will help accelerate the realization of national development. Globalization and urbanization create unlimited competition, thus demanding Indonesia to have good international competitiveness as well. Therefore, human resource development is very important. Human resource management must be balanced between quantity and quality. The Coordinator Ministry for Human Development and Culture notes that people with a high school background make up nearly 90 percent of the labor in Indonesia. The work force originating from universities occupies only about 10 percent. The existence of this fact proves that in the country of Indonesia, the number of skilled labor is not proportional to the challenges that emerged during the era of the 4.0 industrial revolution. The number of skilled labor is minimal. In addition, skill and character education must run with a good nutritional condition. In the Human Capital Life Cycle owned by the Coordinator Ministry for Human Development and culture, it is explained that the first aspect in the scope of life of nutritional intake needs to be prioritized (Murdaningsih and Widyanuratikah, 2020). Labor conditions in Indonesia based on the level of education completed can be seen in Table 3:

Table 3. Employment conditions based on education level (Source: BPS RI, 2018)

\begin{tabular}{|c|c|c|}
\hline Graduate Information & The Number of Labor & Percentage (\%) \\
\hline Primary & $50,458,493$ & 40.69 \\
\hline No/not finished elementary school & $19,197,659$ & 15.48 \\
\hline Primary school & $31,260,834$ & 25.21 \\
\hline Secondary & $58,442,814$ & 47.13 \\
\hline Junior high school & $22,424,728$ & 18.08 \\
\hline Middle School/Vocational High School & $36,018,086$ & 29.05 \\
\hline Tertiary & $15,103,643$ & 12.18 \\
\hline Academy/College & $15,103,643$ & 12.18 \\
\hline Total Works & $124,004,950$ & \multirow{4}{*}{100.00} \\
\hline Labor & $131,005,641$ & \\
\hline Working Age Population & $194,779,441$ & \\
\hline LFPR Value & 67.27 & \\
\hline
\end{tabular}

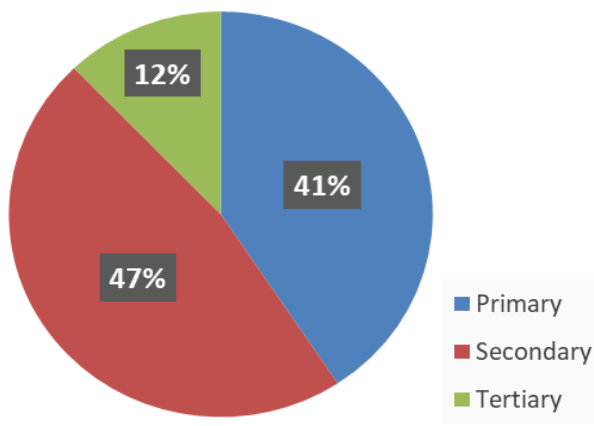

Figure 3. Classification of the Education Level of Indonesian Labor (Source: Processing by researcher using data from BPS RI, 2018)

Education is the key factor to human development (Mwakio, 2017). The level of education will have an effect on their working opportunities. The lower education level, the less job opportunities and income he will receive. Table 3 shows the number of labor based on the last education completed. The largest number of labor are labor with secondary education at the high school or vocational school level. This is in accordance with the records held by the Coordinator Ministry for Human Development and Culture of Indonesia. Figure 3 show the comparison between level of labour education. Compared to the total labor with a tertiary educational background, which is 15 million people, there are far more labor with a secondary education background, which is 58 million people. The figure that is often used to express the number of the labor force is the Labor Force Participation Rate (LFPR), which is the ratio between the total number of labor and the number of the working age population. $L F P R$ can also be referred to as an economic indicator in employment. Therefore, the higher the $L F P R$ rate in an area, the better the economic level of the community. Education continues to be the main factors affecting the benefits of human resources in Indonesia. Education opens up space for the accumulation of knowledge and skills, both technical and cognitive functions that are important to increase productivity. The measure of global competition in education is divided into two, namely basic education and higher education. Higher education is measured by middle and high levels. Then educational participation is also affiliated with training. In terms of quantity, the structure of the labor according to educational background in Indonesia is dominated by their primary school education. This research classified education into three classes, the level of education of the labor in Indonesia can be seen in the Figure 4.

The highest number of secondary, mean labor with junior and senior high school education levels dominate in Indonesia. Labor with secondary education level finds it difficult to compete in formal work and become professionals. Wibowo (2016) said that in reality in the field currently high school graduates, especially vocational schools, are considered not ready to become a labor. The industrial world today wants not only graduates with good grades, but 
graduates who have technical competence and good attitudes. Many high school graduates do not yet have the main competition like what the industry wants, namely hard skills and soft skills. Sometimes between the two abilities, only one is mastered by a high school graduate. Not only vocational high school graduates are required to be people who have the ability to meet the demands of the world of work, but college graduates are the same. Today's university graduates are required to have high creativity, be adaptive, creative, able to think, be able to work across disciplines, and be ready to face the changing times. The Director General of Higher Education, Nizam, hopes that the campus will be able to produce creative and innovative graduates, but still uphold the values of national character. According to him, this is the key for Indonesia to create an advanced Indonesia with superior human resources who are able to compete globally (Prodjo, 2020).

Competitiveness is defined as the conditions of an institution, policies, and factors that determine the level of economic productivity of a country. High productivity reflects high competitiveness, and high competitiveness has the potential to enable high economic growth, which in turn will improve the welfare of the country's people. The inability of Indonesian graduates to compete in the country to find new jobs, will result in many unemployed educated persons. This can happen if Indonesian graduates have much lower skills than other countries. If the problem of unemployment and the quality of the labor can be addressed and increased, it will greatly impact the progress of the Indonesian nation (Putra, 2020). Beyond, labor with low-skill abilities are also needed in the business world. A research showed that labor with low skills are needed in labor-intensive industries. They are hired so that the company can have great benefits from providing low wages (Iqbal, 2017; Puangyoykeaw and Nishide, 2014, 2015).

\section{Development of Indonesia's Global Competitiveness Index}

Vukovic et al. (2012) explain that competitiveness has several definitions and theories. The World Economic Forum defines competitiveness as the set of institutions, policies, and the various factors that determine the level of productivity of a country. The level of productivity of a country will determine the level of prosperity that can be achieved with the economy. The productivity level also determines the rate of return on investment in the economy, which will be the main driver of the growth rate. In other words, a more competitive economy is likely to grow faster (Schwab, 2014). Competitiveness is the foundation of prosperity, based on the economy's productive potential of a country, which in turn is ultimately determined by the productivity of the company as determined by the sophistication of company operations and strategy as well as the quality of the microeconomic business environment. Indonesia, which is a developing country, has become a country that is considered quite competitive. Based on the data contained in the report belonging to the World Economic Forum (WEF), it is known that every year the Indonesia GCI score has fluctuated. Changes in the fluctuating score make the ranking of the Indonesian state also experience a fluctuating phase every year as shown in Figure 5:

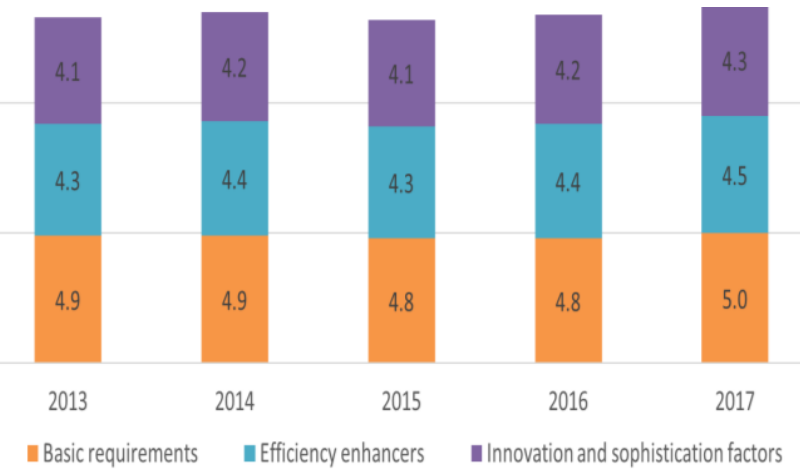

Figure 4. Development of the GCI

Sub-Index in Indonesia (Source: Schwab, 2017)

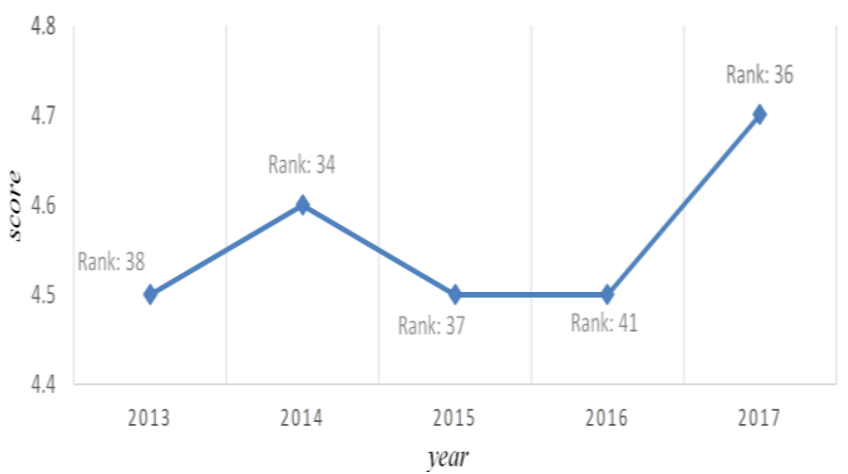

Figure 5. Indonesia's GCI Score and Ranking in 2013-2017 (Source: Schwab, 2014 and 2017)

In 2013 Indonesia had a global competitiveness value of 4.5. In that same year, Indonesia was ranked 38 out of a total of 148 countries. Then, in 2014 Indonesia experienced an increase in value to 4.6 and was ranked 34 . In 2015 Indonesia again experienced a decline of up to 3 ranks with a CGI score of 4.5. In the following year, Indonesia still had the same CGI score, which is 4.5 , but this year Indonesia has again decreased its ranking to rank 41 . This year, Indonesia has a significantly different score from several countries in ASEAN, namely Singapore, Malaysia, and Thailand. Raimanu (2016) states that there are three reasons why Indonesia has experienced a decline, namely the impact of economic policy packages that cannot be felt, faster recovery in other countries, and there are still many structural factors that have not been touched.

Then in 2017, Indonesia experienced an increase in value and ranking on the GCI. In that year Indonesia was ranked $36^{\text {th }}$ with a score of 4.7. Haryanto (2019) said that the increase in Indonesia's position in the GCI ranking was due to improvements in 10 of the 12 pillars that became the basis for the assessment. Indonesia is recognized as having advantages in the pillars of health, basic education and infrastructure. But the WEF also provides recommendations to Indonesia to pay attention to the aspect of equal distribution of GCI indicators. There are several indicators that need attention because they become obstacles in business in Indonesia, particularly corruption, unstable policies, inflation, access to finance, and the quality of human resources which is still quite low (Raimanu, 2016). In 2017. Indonesia has a GDP per capita of US\$ 3,875.8. The average GDP per capita increase in Indonesia over the last 10 years is 5.5. With the amount of GDP possessed by Indonesia, according to the stage, development Indonesia occupies stage 2 (Efficiency Driven). In stage 2, the efficiency enhancer sub-index has the largest percentage compared to other sub-indexes, which is 50\%. Two other sub-indexes, 
namely the Basic requirements sub-index, contributed 40\%. At the efficiency driven stage which contains 5 pillars of the Global Competitiveness Index, Indonesia has the highest score on the Market Size, namely 81.6. then followed by the $5^{\text {th }}$ pillar score with a score of 71.7 and the $6^{\text {th }}$ pillar with a score of 64.1 . Figure 5 shows the development of Indonesia's CGI sub-index. It is known that each of the 2013-2017 pillars experienced an increase and decrease in the graph. The increase in value can occur because in each pillar there are changes caused by the state of growth and development in Indonesia. It can also be seen that every year Indonesia has the largest GCI contribution value in the basic requirements sub-index. This sub-index has a value ranging from 4.8 to 5.0, which is the highest achievement score for Indonesia during the 5-year period, 2013-2017. The sub-index that contributed the least to GCI Indonesia were innovation and sophistication factors, which each year have scores ranging from 4.1 to 4.3. Departing from this, It can be seen that the Indonesian people are still a little weak against today's business sophistication and also new innovations.

\section{Global Competitiveness Index of Indonesia and ASEAN}

Rank of ASEAN Global Competitiveness Index can be seen in Table 4. As one of the countries included in the Association of South East Asian Nation (ASEAN), Indonesia's competitiveness is still below Singapore (ranked 3, with score 5.7), Malaysia (ranked 23, with score 5.2), and Thailand (ranked 32, with score 4.7). Indonesia is ranked $36^{\text {th }}$ with a score of 4.7 in the overall Global Competitiveness Index (GCI). This shows that the ability of Human Resource (HR) in Indonesia is still low. Human resources based on one of the pillars of assessment in Global Competitiveness Index (GCI) released by the World Economic Forum (WEF) in 2018 which is the skill or skills of human resources (HR) Indonesia ranks fourth among the countries in Southeast Asia. Reciprocally, one of the Global Competitiveness Index approach is a human-centric approach, which is an assessment of human resources skills. The assessment covers the effectiveness of education, the level of training of staff, the quality of vocational training and skillset graduates. The covering besides digital skills, ease of finding skilled employees, expectations of a period of education, critical thinking in the learning process, until the pupil-teacher ratio in primary education.

Table 4. Global Competitiveness Index of ASEAN Countries (Source: Schwab, 2017)

\begin{tabular}{|c|c|c|c|c|}
\hline Country & $\begin{array}{c}\text { GCI } \\
\text { Rank }\end{array}$ & $\begin{array}{c}\text { GCI } \\
\text { Score }\end{array}$ & $\begin{array}{c}\text { The } 5^{\text {th }} \\
\text { Rank Pillar }\end{array}$ & $\begin{array}{c}\text { The }^{\text {th }} \\
\text { Pillar Score }\end{array}$ \\
\hline Singapore & 3 & 5.7 & 1 & 6.3 \\
\hline Malaysia & 23 & 5.2 & 45 & 4.9 \\
\hline Thailand & 32 & 4.7 & 57 & 4.6 \\
\hline Indonesia & $\mathbf{3 6}$ & $\mathbf{4 . 7}$ & $\mathbf{6 4}$ & $\mathbf{4 . 5}$ \\
\hline $\begin{array}{c}\text { Brunei } \\
\text { Darussalam }\end{array}$ & 46 & 4.5 & 67 & 4.5 \\
\hline Philippines & 55 & 4.3 & 56 & 4.4 \\
\hline Viet Nam & 55 & 4.4 & 84 & 4.2 \\
\hline Cambodia & 94 & 3.9 & 124 & 2.9 \\
\hline
\end{tabular}

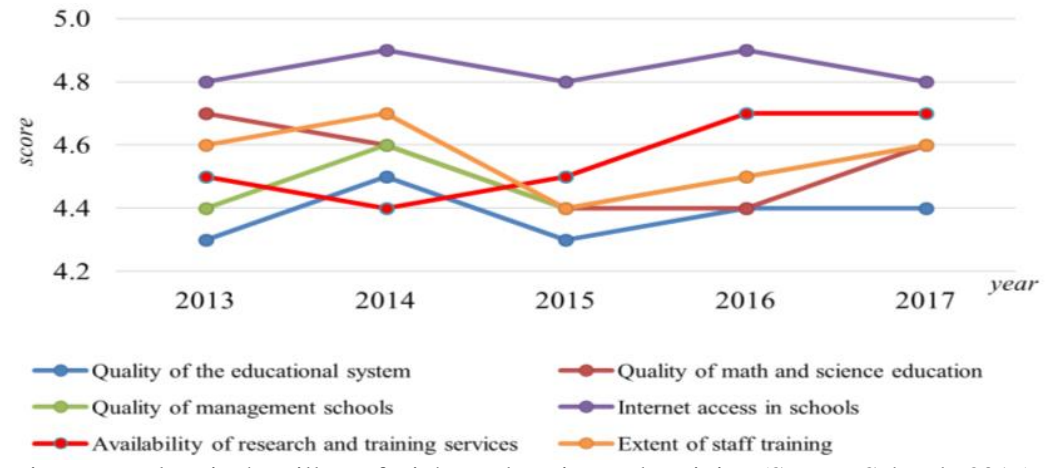

\section{Development of the Pillars of Higher Education and Indonesian training}

Education is a reliable and competitive measure of the ability of human resources to compete with other countries, especially in Southeast Asia. Education has always been the main issue which is still widely debated in all circles. By investing in education, the human resource will be able to compete and survive in the working environment or professional world (Chowa, 2019). The Indonesian education is still weak. This can be seen at least from the number of higher education graduates compared to elementary school graduates. Currently Indonesia is faced with challenges that will change the world of education to become high standard education, foreign educational institutions that continue to develop, as well as the labor market which is being taken over by foreign labor. The government has made efforts to improve the quality of Indonesian education through various policies such as teacher certification, school operational assistance (Bantuan Operasional Sekolah/BOS), grants, and setting national standards. With the existence of national standards, it is hoped that the quality of education in Indonesia will be better. There are obstacles and efforts made by the government to improve the quality of education, including a) curriculum content, b) learning processes and targets, c) educators and educators, d) increasing the level of graduates e) determining expenditure financing, programs $\mathrm{f}$ ) management learning in the form of bilingual, g) perception of assessment, and h) fulfillment of facilities and infrastructure to support the quality of education. Based on the Figure 6, it is known that the quality of education in Indonesia is quite minimal and has fluctuated every year. This occurs in the impression that the centralization policy is more concentrated in Java or it can be referred to as Java Centric. This has resulted in inequality of education in other islands, especially eastern Indonesia. The quality of education equity in Indonesia is supported by government programs, which is accrediting institutions that have been tested by quality indicators. The government initially had a compulsory education program for nine (9) years, then the government changed it to compulsory twelve (12) years.

\subsection{Internet Access}

Nowadays, the world, even Indonesia, has special needs for the internet. Technological Readiness in social economi daily lives also perceived in education (Bhuiyan et al., 2020). The importance of technology also plays a role in the world of education.. The rise of e-learning, the e-library increasingly requires students to master learning devices that 
are directly connected to the internet. The rapid development of technology in the industrial 4.0 era also greatly influenced the characteristics of existing jobs, which in this era focused more on skills and competencies. Because the 4.0 era utilizing the technology in line with the ease of connectivity massive internet was also very influential. Characteristics 4.0 includes digitalization, optimization, and customization of production, automation, and adaptation, the interaction between people and machines, added services and business, automatic data exchange and communication and information technology. The skills become a challenge for the world in which education must collaborate with industry transformation by considering a variety of sectors that may benefit human resources as a driver. The industry besides revolution 4.0 also must respond quickly and precisely to be able to improve Indonesia's competitiveness amid competition. One of the main things to do in higher education institutions is to improve the management of data and information so that information can be conveyed properly to each circle. The good system and good information management will be of interest to prospective students to continue education to a higher level.

\subsection{Education System}

Education remains a major scourge which is still widely a debate in all circles. Indonesia still has a weakness in the field of education that can be seen from at least graduates compared to graduates of primary school, but education is one of the factors capable of human resources that are reliable and competitive to compete with other countries, particularly in Southeast Asia region. Indonesia is faced with the challenges and changes that will occur in the world of education as a high standard of education, foreign education institutions are flourishing, as well as a labor market predicted to be overrun by foreign labor. The government is trying to improve the quality of Indonesian education through various policies such as teacher certification, school operational assistance (Bantuan Operasional Sekolah/BOS), block grants and setting national standards. With the existence of these national standards, it is expected that the quality of education in Indonesia will fluctuate. The government has found a bright spot where the number of graduates at the junior secondary level always experiences an increase every year. There are obstacles and efforts made by the government to improve the quality of education, including a) the contents of the curriculum, b) the process and learning targets, c) educators and educators, d) increase the level of graduates e) determination of expenditure financing, $\mathrm{f}$ ) management learning programs in the form of bilingual, g) perception of assessment, and $\mathrm{h}$ ) fulfilment of facilities and infrastructure as a support for the quality of education.

\subsection{Higher Education Participation}

Education is an important role that can be a determining factor, especially regarding human resources. Decisions in education are influenced by not only personal characteristics but also family and regional characteristics. Higher education also has functions for the world of education in Indonesia, among others, to help, create, promote and share knowledge through the academic process. High education can also be a driving factor for the birth of an educated professional labor.

The government's effort to improve the quality of higher education is to develop the infrastructure of educational institutions. Higher education is very influential as the relevance of labor needs in the global era. Then the fact of the challenge for labor in the global era is the absence of job opportunities as a result of instability and fluctuations in the global economy. If we look at the trend towards the proliferation of young people, educated unemployment is one indication of this. Various factors influence the occurrence of unemployment fluctuations including; a) entry of foreign labor with far better qualifications, b) an increase in the number of tertiary institutions with inadequate qualifications, and c) competition in the world of education which continues and is getting tighter.

\subsection{Digital Infrastructure in School}

Infrastructure is often intersecting with the narrower sense, as we all know are things that have a physical form, but said infrastructure does not necessarily have a physical form. Non-physical infrastructure development in the area of education like a digital library is one of the infrastructure development efforts embedded with internet access installed in the library as a complementary means of a computer. One of the benefits offered by digital infrastructure is rapid support to science. The rapid mark has been started when the great universities in various countries complement the high-performance computers and the availability of laboratories in various research centers who started using computers with high performance. The development of technology that is used for scientific purposes, came to the idea of cyber-infrastructure and e-science which previously put forward the machinery and engineering, as time goes processing able to propagate the information, communications, data, and storage. The phenomenon of the explosion of information that can be accessed by all parties to encourage scientists to conduct studies has grid-computing. The original grid-computing concept as mass user activity on the computer where the network resources are in the form of a heterogeneous or not centralized. Indonesia government has made an effort to use the Palapa Ring which is predicted to become a bridge of communication between the island which is also a means of support to the 4.0 industrial revolution. Governance strives for challenges in digital infrastructure development in the area of education is its connectivity. Connectivity is the key to the spread of data and opera-widely.

\section{Development of the Pillars of Higher Education and Training in Indonesia and ASEAN}

Based on a report by the World Economic Forum, in 2017 Indonesia was ranked 64th globally in the higher education and training pillars. When compared with other ASEAN countries, it can be seen in Figure 7 that Indonesia is in $5^{\text {th }}$ place out of 10 other ASEAN countries. Singapore is a country in ASEAN that is included in the top 2 countries with the highest Global Competitiveness Index in the field of education. Then followed by Malaysia which is ranked $46^{\text {th }}$ globally and Brunei Darussalam at $55^{\text {th }}$ globally. Unlike Singapore, Myanmar is a country in ASEAN with a relatively low ranking globally. Myanmar is the last country in the education sector in ASEAN, while globally, the country is at number 139. 


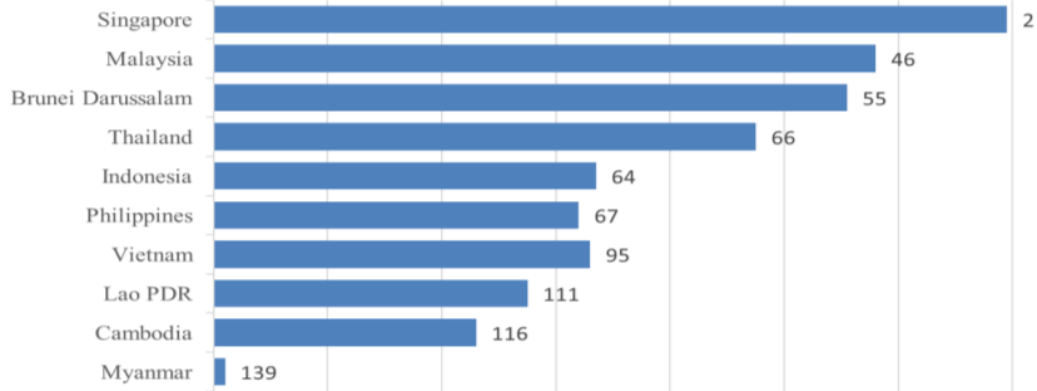

Figure 7. ASEAN Higher Education and Training 2017 Rankings (Source: Schwab, 2017)
Table 5. Correlation Test Results

\begin{tabular}{|c|c|c|}
\hline & $\begin{array}{c}\text { Spearman's Correlation Test } \\
\text { The Global } \\
\text { Competitiveness } \\
\text { Index }\end{array}$ & $\begin{array}{c}\text { Global } \\
\text { Competitiveness } \\
\text { Index }\end{array}$ \\
\hline $\begin{array}{c}\text { Correlation } \\
\text { Coefficient }\end{array}$ & $\mathbf{0 . 8 7 4} * *$ & $\mathbf{0 . 8 5 0} * *$ \\
\hline $\begin{array}{c}\text { Sig. (2- } \\
\text { tailed) }\end{array}$ & 0.005 & 0.007 \\
\hline $\mathrm{N}$ & 8 & 8 \\
\hline
\end{tabular}

\section{The relationship between the Human Development Index and the $5^{\text {th }}$ Pillar of the Global Competitiveness Index}

The relationship between the Human Development Index (HDI) and the $5^{\text {th }}$ pillar of Global Competitiveness (GCI), namely Higher Education and Training, is seen using the correlation test. Correlation test was performed using nonparametric spearman correlation. Non-parametric analysis is used because the data owned by the researcher does not meet the requirements for doing a parametric analysis. Variables that are more than 2, the number of data samples owned by the researcher is less than 30, and the type of data held is in the form of nominal or numerical data, this is the reason for the use of non-parametric analysis in the correlation test of this research. The following results of the correlation test can be seen in Table 5. The correlation test using the Spearman method shows that there is a relationship between the Human Development Index (HDI) variable and the $5^{\text {th }}$ pillar of the Global Competitiveness Index (GCI) and the overall Global Competitiveness Index (GCI). Based on Table 5 above, it can be seen that the correlation between HDI and CGI pillar 5 is 0.874 with a significance of 0.005 , while the result of the correlation between HDI and GCI as a whole is 0.850 with a significance of 0.007 . The results show that there is a relationship between the three variables that the researcher uses. The relationship between the three variables is a strong relationship because the value is above 0.7 . The significance of $<0.05$ also shows that the correlation between the three variables is significant. Based on the explanation above, it can be seen that the Human Development Index is related to the Global Competitiveness Index, so it can be said that the development of the quality of human resources is related to global competitiveness. In addition, one of the basic factors in the Human Development Index and the Global Competitiveness Index is education. The better the quality of education, the better the quality of human resources and global competitiveness. This of course also applies in Indonesia. If the government wants to make Indonesia more advanced, changes must be made to its human resources. This is also in line with the opinion of Sulisworo (2016) in his research entitled "The Contribution of the Education Quality System to Improve the Nation's Competitiveness of Indonesia", He said that education is the best strategy in improving the quality of human resources.

\section{CONCLUSIONS}

In the era of industrial revolution 4.0, good quality of human resources is currently needed. The labor is required to be competitive, innovative and capable to solve things. Participation in ASEAN Economic Community (AEC) has challenge Indonesia to optimize natural resources and human resources. Good resource management will help accelerate the realization of national development. Currently, the Indonesia Coordinating Ministry of Human Development and Culture notes that 90 percent of Indonesia's labor are secondary school graduates. The level of education of a person affects the opportunity to work. Among several other ASEAN countries, Indonesia is still in the $4^{\text {th }}$ or $5^{\text {th }}$ place. This shows that the ability of Human Resource (HR) in Indonesia is still low level. Relationship between the Human Development Index (HDI) and the Global Competitiveness Index (GCI) was carried out by using Spearman Non-Parametric Correlation. The correlation between the $5^{\text {th }}$ pillar of HDI and CGI is 0.874 with a significance of 0.005 , while the result of the HDI correlation between HDI and GCI as a whole is 0.850 with a significance of 0.007 . This represents that human resources quality development is related to global competitiveness. Human resources enhancement will also have a positive impact on global competitiveness through improving the education level. Meanwhile, the thing that can obstruct the global competitiveness enhancement in Indonesia is the high corruption rate that exists within Indonesia's human resource. Until now, the government's main focus has been on corruption eradication. But this will not be possible if the corruption eradication is not carried out from an early age, which is providing equal education as capital to achieve national development.

\section{REFERENCES}

Adam, L. (2017). Membangun Daya Saing Tenaga Kerja Indonesia Melalui Peningkatan Produktivitas [Building the Indonesian Labor Competitiveness through Increased Productivity]. Jurnal Kependudukan Indonesia, 11(2), 71-84 (in Indonesian). https://doi.org/10.14203/jki.v11i2.205

Afandi, T. (2017). Komitmen Serius Indonesia Dalam Melaksanakan Sustainable Development Goals 2015-2030 [Indonesia's Serious Commitment to Implementing the 2015-2030 Sustainable Development Goals]. Kemterian PPN/Bappenas Berita dan Siaran Pers. https://www.bappenas.go.id/files/9915/0397/6784/Siaran_Pers_-

_Komitmen_Serius_Indonesia_dalam_Melaksanakan_Sustainable_Development_Goals_2015-2030.pdf

Ayu, N.A.K. (2018). Peluang dan Tantangan Bonus Demografi Indonesia dalam Era Revolusi Industri 4.0 [Opportunities and Challenges of Indonesian Demographic Bonus in the Industrial Revolution 4.0 Era]. Forbil Institute: Correct Policy for Indonesia website: https://forbil.org/id/article/251/peluang-dan-tantangan-bonus-demografi-indonesia-dalam-era-revolusi-industri-40

Bhuiyan, M.B., Islam, M.A., Haque, M.Z., \& Biswas, C. (2020). Moderating Effect of Technology Readiness on Adoption of Geotagging Technology Among Social Networking Sites (SNSS) Users for Smart Tourism. GeoJournal of Tourism and Geosites, 34(1), 47-55. https://doi.org/10.30892/gtg.34107-618 
Budiati, I., Susianto, Y., Adi, W.P., Ayuni, S., Reagan, H.A., Larasaty, P., \& Saputri, V.G. (2018). Profil Generasi Milenial Indonesia [The Profile of Indonesian Millennials generation], 8-115, Jakarta: Kemenpppa. https://www.kemenpppa.go.id/lib/ uploads/list/9acde-buku-profil-generasi-milenia.pdf

Chowa, G. (2019). The Next Frontier for Social Development: Deepening Our Understanding, Discovering New Solutions, and Forging Ahead. Global Social Welfare, 6(1), 1-3. https://doi.org/10.1007/s40609-019-00145-4

de Saxe Zerden, L., Lombardi, B.M., \& Guan, T. (2019). Integrated Behavioral Health and Social Work: a Global Perspective. Global Social Welfare, 6(1), 49-56. https://doi.org/10.1007/s40609-018-0114-z

Deffinika, I. (2014). Masyarakat Ekonomi ASEAN dalam Menghadapi Tantangan Global [ASEAN Economic Community In Facing The Global Challenges]. Jurnal Kawistara, 6(3), 318-320, (in Indonesian).

Garidzirai, R., \& Takudzwa Pasara, M. (2020). An Analysis of the Contribution of Tourism on Economic Growth in South African Provinces: A Panel Analysis. GeoJournal of Tourism and Geosites, 29(2), 554-564. https://doi.org/10.30892/gtg.29214-489

Haryanto, J.T. (2019). APBN 2019 dan Peningkatan Daya Saing Indonesia [Indonesia 2019 State Budget and the Increasing Competitiveness]. Artikel dan Opini Kemenkeu. https://www.kemenkeu.go.id/publikasi/artikel-dan-opini/apbn-2019-dan-peningkatan-daya-saing-indonesia/

Haryono, S. (2018). Re-Orientasi Pengembangan SDM Era Digital Pada Revolusi Industri 4.0 [Re-Orientation of the Development of Human Resources in the Digital Age in the Industrial Revolution 4.0]. The National Conference on Management and Business (NCMAB) 2018 Fakultas Ekonomi Dan Bisnis Universitas Muhammadiyah Surakarta, 1-15, (in Indonesian).

Iqbal, A. (2017). Experiences of Highly Skilled Migrants in New Zealand: Challenges for Professional Integration. Global Social Welfare, 4(4), 191-197. https://doi.org/10.1007/s40609-017-0082-8

Khan, M.A., Banerjee, S., \& Alok, S. (2021). Building an Inclusive Talent Pipeline: A Study on Women of the Indian Informational Technology Sector. Journal of International Women's Studies, 22(4), 97-117. https://vc.bridgew.edu/cgi/viewcontent.cgi?article=2431\&context=jiws

Murdaningsih, D., \& Widyanuratikah, I. (2020). Angkatan kerja Indonesia Masih Mendominasi Lulusan SLTA [High School Graduates Dominates in Indonesian Workforce]. Republika Online Pers. https://republika.co.id/berita/q67dao368/angkatan-kerja-indonesiamasih-didominasi-lulusan-slta

Mwakio, N. (2017). Overcoming Obstacles to Educational Access for Kenyan Girls: A Qualitative Research. Journal of International Women's Research, 18(2), 259-274. https://vc.bridgew.edu/cgi/viewcontent.cgi?article=1943\&context=jiws

Nursyamysi, M., \& Subarkah, M. (2016). Ini Keunggulan Indonesia Hadapi MEA [This is Indonesia's superiority in facing the MEA]. Republika News. https://republika.co.id/berita/nasional/umum/16/01/03/o0dgkk385-ini-keunggulan-indonesia-hadapi-mea

Pramono, W.T., \& Rofi, A. (2013). Hubungan Penanaman Modal Asing masuk Terhadap Indeks Pembangunan Manusia di Asia Tahun 2005-2010 [The Relationship of Foreign Investment Toward Human Development Index in Asia 2005-2010]. Jurnal Bumi Indonesia, 1(3), (in Indonesian). http://lib.geo.ugm.ac.id/ojs/index.php/jbi/article/view/112/109

Prodjo, W.A. (2020). Era Disrupsi, Kampus Diharapkan Cetak Lulusan Seperti Ini [Disruption Era, University is Expected To Form Graduated Like This]. Kompas.com. https://edukasi.kompas.com/read/2020/06/18/070000171/era-disrupsi-kampus-diharapkan-cetak-lulusan-seperti-ini-

Puangyoykeaw, K., \& Nishide, Y. (2014). Needs perception, position, and contentment: An empirical study of Myanmar immigrant workers in Thailand. European Journal of Business and Social Sciences, 3(4), 93-101.

Puangyoykeaw, K., \& Nishide, Y. (2015). Organizational Commitment and Turnover Intention in Low-Skilled Immigrant Labor in Thailand: An Empirical Assessment of Need Satisfaction, Job Satisfaction and Overall Life Satisfaction Factors. International Journal of Business and Management, 10(5). https://doi.org/10.5539/ijbm.v10n5p98

Puri, I.W. (2014). Pahami Masyarakat Ekonomi ASEAN (MEA) 2015 [Understand the 2015 ASEAN Economic Community (AEC)]. National Geographic Indonesia. https://nationalgeographic.grid.id/read/13295658/pahami-masyarakat-ekonomi-asean-mea-2015

Putra, E.P. (2020). Tantangan Menciptakan tenaga Kerja Profesional [The Challenge of Creating a Professional Workforce]. Republika.co.id. https://republika.co.id/berita/nfpgb6/tantangan-menciptakan-tenaga-kerja-profesional

Raimanu, G. (2016). Analisis Daya Saing Indonesia Tahun 2016-2017: Sebuah Analisis Kebijakan Manajemen Keuangan Internasional. Universitas Tadulako. [Analysis of Indonesia's Competitiveness 2016-2017: An Analysis of International Financial Management Policies. http://www. researchgate. net/publication/311594011 [13 Februari 2018].

Schwab, K. (2014). The Global Competitiveness Report 2014-2015. xiii-102, Ganeva: World Economic Forum.

Schwab, K. (2017). The Global Competitivness Report 2016-2017. 128-362, Ganeva: World Economic Forum.

Schwab, K. (2018). The Global Competitivness Report 2018. 37-647, Ganeva: World Economic Forum.

Sulisworo, D. (2016). The Contribution of the Education System Quality to Improve the Nation's Competitiveness of Indonesia. Journal of Education and Learning (EduLearn), 10(2), 127-137. https://doi.org/10.11591/edulearn.v10i2.3468

Suratini (2017). Pengaruh Pendidikan dalam Meningkatkan Kualitas Sumber Daya Manusia di Indonesia [The Effect of Education in Improving the Quality of Human Resources in Indonesia]. Future: Jurnal Manajemen Dan Akuntansi, 5(1), 68-84 (in Indonesian). https://www.neliti.com/id/publications/266064/pengaruh-pendidikan-dalam-meningkatkan-kualitas-sumber-daya-manusia-di-indonesia\#cite

Umar, M.A. (2018). Bonus Demografi Sebagai Peluang dan Tantangan Pengelolaan Sumber Daya Alam Di Era Otonomi Daerah. [Demographic Bonuses as Opportunities and Challenges in the Era of Regional Autonomy]. Genta Mulia: Jurnal Ilmiah Pendidikan, 8(2), 90-99 (in Indonesian).

Ventura, B. (2018). 10 Negara Ekonomi Berdaya Saing Tinggi di Dunia [10 Country with High Competitive Economy in the World]. Sindonews.com. https://ekbis.sindonews.com/berita/1347008/35/10-negara-ekonomi-berdaya-saing-tinggi-di-dunia

Vuković, D., Jovanović, A., \& Đukić, M. (2012). Defining competitiveness through the theories of new economic geography and regional economy. Journal of the Geographical Institute Jovan Cvijic, SASA, 62(3), 49-64. https://doi.org/10.2298/IJGI1203049V

Wibowo, N. (2016). Upaya Memperkecil Kesenjangan Kompetensi Lulusan Sekolah Menengah Kejuruan dengan Tuntutan Dunia Industri [Efforts to Reduce the Competency Gap of Vocational High School Graduates With the Demands of the İndustrial World]. Jurnal Pendidikan Teknologi Dan Kejuruan, 23(1), 45-50 (in Indonesian). https://doi.org/10.21831/jptk.v23i1.9354

Zubaidah, N. (2019). Menyeimbangkan Tiga Skill [Balancing the Tree Skills]. Koran Sindo. https://nasional.sindonews.com/berita/ 1390754/144/menyeimbangkan-tiga-skills

***BPSRI. (2018). Keadaan Angkatan Kerja di Indonesia Agustus 2018 [Labor Force Situatuon in Indonesia Agust 2018]. 3-228, Jakarta: Badan Pusat Statistik Indonesia.

*** Indonesian Ministry of Industry. (2018). Revolusi Industri 4.0 Buka Peluang Dongkrak "Skill” SDM [Industrial Revolution 4.0 Opens Opportunities to Boost HR "Skills"]. In Siaran Pers. Kemenperin. https://kemenperin.go.id/artikel/19676/Revolusi-Industri4.0-Buka-Peluang-Dongkrak-'Skill'-SDM\#: :text=Era revolusi industri 4.0 membuka,sesuai dengan perkembangan teknologi terkini.\&text="Di dalam roadmap Making Indonesia,prioritasnya adalah peningkatan

***Warta Ekspor. (2015). Peluang dan Tantangan Indonesia: Pasar Bebas ASEAN [Opportunities and Challenges for Indonesia: ASEAN Free Market]. Peluang Dan Tantangan Indonesia Pasar Bebas ASEAN: Masyarakat Ekonomi ASEAN (MEA). http://djpen. kemendag.go.id/app_frontend/admin/docs/publication/7551442304774.pdf 